AJHSE Vol: 2 (2): 109-115, 2021

DOI: 10.52417/ajhse.v2i2.164

Accepted Date: Sept. 30, 2021

(C) 2021. CC License 4.0

www.ajhse.org

\title{
FUNGAL COMPOSITION AND PROXIMATE ANALYSIS OF POULTRY FEEDS SOLD IN BENIN CITY, NIGERIA
}

\author{
${ }^{* 1}$ Ogbebor, A. S., ${ }^{2}$ Imoni, A. A. \& ${ }^{3}$ Ohiorenoya, O. R. \\ *1,2£3 Department of Microbiology, University of Benin (UNIBEN), Benin City, Edo State, Nigeria. \\ *Corresponding Author's E-mail: agbonomaire.igbinedion@uniben.edu, augustina.imoni@uniben.edu, oisaohio@gmail.com \\ Phone: $+2347034580512_{2}+2348025348985,+2348075329097$
}

\begin{abstract}
$\mathrm{P}$ oultry farming contributes significantly to poverty alleviation by providing employment opportunities to Nigerians. Feed quality is the most prominent challenge of the poultry sector. This study was aimed at assessing the fungal and proximate qualities of poultry feeds sold in Benin City, Nigeria. Poultry feed samples (starter, grower and finisher) were obtained from five stores in Benin City. Enumeration and isolation of fungi was carried out using the spread plate method on potato dextrose agar and Aspergillus flavus and parasiticus agar (AFPA). Identification of fungal isolates was based on cultural and morphological characteristics. Proximate composition was determined by standard methods. The total fungal counts of starter, grower and finisher feeds ranged from $0.10-8.50 \times 10^{5} \mathrm{sfu} / \mathrm{g}$. Fungal species isolated were Aspergillus flavus, Aspergillus niger, Penicillium spp., Saccharomyces spp., Trichoderma spp., Rhizopus spp. and Mucor spp. The results from proximate analysis were as follows: $36.50 \pm 0.92-70.92 \pm 0.51 \%$ (protein), $3.53 \pm 0.04-8.45 \pm 0.16 \%$ (fibre), $11.61 \pm 0.72-13.91 \pm 0.27 \%$ (fat), $2.70-8.60 \%$ (moisture content) and $3.65-37.83 \%$ (carbohydrate). The temperature and relative humidity of storage ranged from $33.90^{\circ} \mathrm{C}-35.20^{\circ} \mathrm{C}$ and $69 \%-75 \%$ respectively. Results showed that poultry feeds sampled have diverse fungi present in them. Control measures should be adhered to in poultry industries and stores to prevent microbial contamination.
\end{abstract}

Keywords: aflatoxigenic fungi, feed storage fungal contamination, poultry feeds, proximate quality

LICENSE: This article by African Journal of Health, Safety and Environment (AJHSE) is licensed and published under the Creative Commons Attribution License 4.0 International License, which permits unrestricted use, distribution, and reproduction in any medium, provided this article is duly cited.

COPYRIGHT: The Author(s) completely retain the copyright of this published article.

OPEN ACCESS: The Author(s) approves that this article remains permanently online in the open access (OA) model

QA: This Article is published in line with "COPE (Committee on Publication Ethics) and PIE (Publication Integrity \& Ethics)". 


\section{INTRODUCTION}

Poultry farming contributes significantly to poverty alleviation by providing employment opportunities to Nigerians. Feed quality is the most prominent challenge of the poultry sector (Dewa and Tikau, 2019). The safety and quality of feed are currently of major concern in developed countries, as safety of feed is a fundamental requirement for all birds. Unsafe feed can lead to great economic losses (Danbappa et al., 2018). Feed is the most important variable cost component, accounting for about $65-70 \%$ of production cost (Dewa and Tikau, 2019). Therefore, for efficiency and high productivity, birds must be fed with quality feed to meet their nutritional requirements, hence the need for qualitative feed cannot be over emphasized (FAO, 2013). Healthy poultry require adequate amounts of carbohydrates, lipids and proteins along with necessary vitamins and dietary minerals. These nutritional components are important for the development and growth of farm animals (Dmello and MacDonald, 1998). There are different types of feeds given to poultry. They include starters, growers, layers and finisher feeds (Ubiebi, 2017). The raw materials used for the formulation of feeds are sourced from different origin including animal and plant, most are mainly agro-wastes. Most of these feed additives have been implicated as the primary sources of microorganisms of public health concern in poultry feeds (Afolayan and Afolayan, 2008; Matthew et al., 2017).

Several microorganisms can contaminate poultry feeds. Species of Aspergillus and Penicillium are frequently isolated as contaminants from feeds (Mehrolia et al., 2015). Feed materials may become contaminated with microorganisms during growing, harvesting, processing, storage and dispersal of the feed (Ubiebi, 2017). Contamination can arise from air, equipment, feed ingredients, farm workers, handling and raw materials. A number of poultry diseases of various pathology and origins including viral, bacterial and fungal have been attributed to poultry feeds. Examples are Avian influenza, New Castle disease, salmonellosis, aspergillosis and candidiasis. The consumption of mycotoxins can result in immunosuppression (Macrowioski et al., 2006; Danbappa et al., 2018). The components of feed especially corn and corn by-products are the most susceptible to aflatoxigenic fungi attack and therefore aflatoxin contamination. Aflatoxins are mould-synthesized, secondary metabolites that are capable of causing disease and death in humans and animals (Granadas-Chinchilla, 2017). The contamination of forages and cereals by mycotoxigenic fungi often occur in the field or during processing, transportation and storage when conditions for growth such as temperature and relative humidity are suitable (Mgbeahuruike et al., 2020).

The presence of fungi affects the organoleptic attributes and nutritional quality of feeds. Moulds will assimilate and utilise the readily available nutrients in the feed thereby leading to loss of nutrients in the feed and spoilage (Danbappa et al., 2018). The genera of most concern globally in poultry feeds are Aspergillus, Penicillium and Fusarium (Ghaemmaghami et al., 2018). The identification of contaminating fungi is essential because it is a helpful indicator to determine feed quality and also provides data on the potential production of mycotoxins. This study was aimed at assessing the fungal and proximate qualities of poultry feeds sold in Benin City, Nigeria. 


\section{METHODOLOGY SAMPLE COLLECTION}

Three forms of poultry feeds; starter, grower and finisher from were sampled in five (5) feed stores in Benin City, Edo State, Nigeria. The samples were collected aseptically using sterile spatula in sterile polyethylene bag and labelled accordingly.

\section{ENUMERATION AND ISOLATION OF FUNGI}

The fungi were isolated by serial dilution and the spread plate method. Poultry samples were serially diluted and $0.10 \mathrm{ml}$ (dilution $10^{-3}$ ) of samples was inoculated on potato dextrose agar (PDA) and Aspergillus flavus and parasiticus agar (AFPA). The inoculated plates were incubated at $28 \pm 2^{\circ} \mathrm{C}$ for 3-5 days. Colonies that developed were counted and recorded as spore-forming units per gram (sfu/g). Pure cultures were obtained by sub-culturing and identification was done by cultural and microscopic characterisation. One drop of lactophenol cotton blue stain was placed on a clean glass slide. A sterilized inoculating pin was used to pick suspected fungal colony placed in the stain on the slide. This was then teased out and covered with glass cover slip. The slide was observed under $\times 40$ magnification of a light microscope. Microscopic characteristics of fungi such as hyphae, conidial heads and arrangements of conidia were observed (Barnet and Hunter, 1972).

\section{PROXIMATE ANALYSIS}

The crude protein, fibre, ash, fat, total carbohydrate and moisture contents of the poultry feeds were analysed according to standard methods given in Association of Official Analytical Chemists (AOAC, 2016). Relative humidity and temperature of the feed stores were determined using a thermometer humidity meter (ThermoPro Model TP49-W2) by methods described by Nwabueze and Nwabueze (2011).

\section{RESULTS AND DISCUSSION}

The evaluation of fungal contamination in poultry feeds is one of the important steps taken to control feed quality and hygiene. The total fungal counts of starter, grower and finisher feeds ranged from $0.10 \times 10^{5}-8.50 \times 10^{5} \mathrm{cfu} / \mathrm{g}$. The fungal count of the poultry feeds exceeded the accepted European standard for finished poultry feed $\left(1 \times 10^{5}\right.$ cfu/g) (Ghaemmaghami et al., 2018). The high fungal counts depict the level at which feed ingredients used in feed formulation is contaminated. The condition of feed storage and handling is a source of contamination. There is a build-up of microbial contamination when feeds are not hygienically handled and stored (Ubiebi, 2017). The fungal species isolated from poultry feeds sampled in this study include Aspergillus flavus, Aspergillus niger, Penicillium spp., Saccharomyces spp., Trichoderma spp., Rhizopus spp. and Mucor spp. Similar fungi including Aspergillus niger, Mucor spp., Rhizopus spp., Fusarium spp., Penicillium spp., and Cladosporium spp. were also isolated and identified from poultry feeds sampled by Danbappa et al. (2018). Ghaemmaghami et al. (2018) also reported that Fusarium species, yeast and Aspergillus species were the most frequently recovered genera from mashed and pelleted feeds. It is reported that some species of Rhizopus are also mycotoxigenic (Matthew et al., 2017). The feed ingredients and nutritional quality of feed can influence the capability of fungi to inoculate and make use of their genetic machinery to produce aflatoxins within the substrate. Feed is especially susceptible to aflatoxin 
contamination (Granadas-Chinchilla, 2017). The isolation of aflatoxigenic fungi; Aspergillus flavus from poultry samples in this study is of great public health concern. Agricultural raw materials that are contaminated with fungi and used for the manufacture of poultry feeds may have adverse effects on the animal's health and productivity (Mehrolia et al., 2007).

Vakili et al. (2015) reported that the major nutrients of poultry feed that are considered for formulating diets are crude protein, moisture, crude fibre, calcium and phosphorus. Contamination of feeds by moulds may decrease nutritional value and affects animal health (Obiajuru et al., 2015). The results from the proximate composition of the poultry feeds (starter, grower and finisher) are shown in Table 3. The protein content of the poultry feed samples ranged from $36.50 \pm 0.92-70.92 \pm 0.51 \%$. Crude protein is one of the most important nutrients to quantify in a prospective feed, due to the fact that a deficiency of protein has a drastic effect on growth and production. Starter rations are generally higher in protein whereas grower and finisher feeds usually contain lesser protein, because old birds need less (Vakili et al., 2015). The moisture content ranged from $2.70-8.60 \%$. According to Vakili et al. (2015), the standard moisture content for poultry feeds ranges from 10.30-11.00\%. A high moisture content can affect the shelf life of feeds, thereby making them unsuitable for long storage. However, the moisture content of the feeds analysed in this study were low, this could be the reason for the high level of fungi obtained in this study (Matthew et al., 2017). The fat content ranged from $11.61 \pm 0.72-13.91 \pm 0.27 \%$, which is greater than the recommended requirements by NRC (1994). A high fat content indicates a good source of energy to poultry. The carbohydrate contents of the sampled poultry feeds were high except for starter feeds. A high carbohydrate content indicates availability of energy in the feeds.

The important factors for optimal feed storage are suitable temperature and humidity, hygiene, a place to store feed away from pesticides, direct sunlight, water and damp (Sukmawati et al., 2018). The temperature and relative humidity of storage ranged from $33.90^{\circ} \mathrm{C}-35.20^{\circ} \mathrm{C}$ and $69 \%-75 \%$ respectively. Mehrolia et al. (2007) reported that temperature and humidity above $30^{\circ} \mathrm{C}$ and $80-100 \%$ respectively are favourable for fungal growth. Ghaemmaghami et al. (2018) noted that many studies have suggested that the presence of Aspergillus might potentially lead to mycotoxin production when processes of storage and transportation are not appropriate.

Table 1: Fungal Count of Poultry Feeds Sold in Benin City

\begin{tabular}{ll}
\hline Sample & Fungal Count $\left(\times 10^{5} \mathrm{cfu} / \mathrm{g}\right)$ \\
\hline A (Finisher E) & $0.10 \pm 0.00$ \\
B (Grower F) & $2.00 \pm 0.00$ \\
C (Finisher F) & $0.60 \pm 0.00$ \\
D (Starter F) & $0.10 \pm 0.00$ \\
E (Grower E) & $8.50 \pm 1.00$ \\
F (Starter E) & $3.00 \pm 2.00$ \\
G (Starter D) & $1.00 \pm 0.50$ \\
H (Starter C) & $0.50 \pm 0.00$ \\
I (Finisher C) & $0.20 \pm 0.00$ \\
J (Finisher B) & $1.55 \pm 0.50$ \\
K (Grower B) & $1.55 \pm 0.50$ \\
L (Grower C) & $1.05 \pm 0.50$ \\
M (Grower A) & $0.75 \pm 0.20$ \\
N (Finisher A) & $3.15 \pm 1.50$ \\
O (Starter A) & $0.65 \pm 0.04$ \\
\hline
\end{tabular}


Table 2: Percentage Occurrence of Fungal lsolates from Poultry Feed Samples.

\begin{tabular}{lll}
\hline Organism & Frequency & Percentage (\%) \\
\hline Mucor sp. & 3 & 12.50 \\
Penicillium sp. & 1 & 4.17 \\
Aspergillus niger & 2 & 8.33 \\
Aspergillus flavus & 4 & 16.66 \\
Saccharomyces cerevisiae & 12 & 50.00 \\
Trichoderma sp. & 1 & 4.17 \\
Rhizopus sp. & 1 & 4.17 \\
Total & 24 & 100 \\
\hline
\end{tabular}

Table 3: Proximate Quality of the Poultry Feeds Samples

\begin{tabular}{lllllll}
\hline Sample & Ash (\%) & Fat (\%) & Fibre (\%) & Protein (\%) & $\begin{array}{l}\text { Moisture } \\
(\%)\end{array}$ & $\begin{array}{l}\text { Carbohydrate } \\
(\%)\end{array}$ \\
\hline Starter & $3.69 \pm 0.32$ & $13.91 \pm 0.27$ & $3.53 \pm 0.04$ & $70.92 \pm 0.51$ & 4.30 & 3.65 \\
Grower & $4.70 \pm 0.33$ & $12.50 \pm 0.07$ & $8.45 \pm 0.16$ & $41.00 \pm 0.61$ & 8.60 & 27.71 \\
Finisher & $4.99 \pm 0.33$ & $11.16 \pm 0.72$ & $6.82 \pm 0.41$ & $36.50 \pm 0.92$ & 2.70 & 37.83 \\
\hline
\end{tabular}

Table 4: Temperature and Relative Humidity of the Poultry Feed Stores

\begin{tabular}{ccc}
\hline Stores & Temperature $\left({ }^{\circ} \mathbf{C}\right)$ & Relative Humidity $(\%)$ \\
\hline A & 33.90 & 71 \\
B & 34.80 & 75 \\
C & 35.10 & 72 \\
D & 34.10 & 66 \\
E & 35.20 & 65 \\
\hline
\end{tabular}

\section{CONCLUSION}

Most of the fungi isolated from this study are potentially toxigenic, making it necessary to establish quality control measures that will be adhered to during formulation, packaging, transport, storage and use. There is need to store feeds properly to avoid moisture uptake and damage by heat. Feeds should be stored suitably where it cannot be attacked by microorganisms, insects and rodents. Good manufacturing practice, handling and retailing methods should be improved to enhance the microbial quality of these products. It is highly recommended that government and public health organizations should raise awareness on poultry diseases that could be contracted from the consumption of contaminated feeds. 


\section{REFERENCES}

Afolayan, M. O. and Afolayan, M. (2008). Nigeria oriented poultry feed formulation software requirements. Journal of Applied Sciences Research, 4(11): 1596-1602.

Association of Official Analytical Chemists (AOAC) (2016). Official Method of Analysis of the Association of Official Analytical Chemists (20 ${ }^{\text {th }}$ Edition). Washington D. C 782pp.

Barnett, H. L. and Hunter, B. B. (1972). Illustrated Genera of Imperfect Fungi. ( ${ }^{\text {rd }}$ edition) Burgess Publishing Co., Minneapolis. 241pp.

Danbappa, R.A., Alhassan, K. A. and Shah, M.A. (2018). Isolation and identification of microbial contaminants associated with commercial poultry feeds. Journal of Applied and Advanced Research, 3(5): 142-147. https://doi.org/10.21839/jaar.2018.v3i5.231

Dewa, U.A. and Tikau, F. (2019). Proximate and elemental analysis of some selected commercial poultry feeds in Nigeria. Caliphate Journal of Science and Technology, 2: 148-153.

Dmello, J.P.F. and Macdonald, A.M.C. (1998). Fungal toxins as disease elicitors. In J. Rose, (Ed.), Environmental Toxicology: Current Developments (pp. 253-289) Amsterdam, Netherlands: Gordon and Breach Science Publishers. https://doi.org/10.4324/9780203305515_chapter_13

Food and Agricultural Organisation (FAO) (2013). Poultry development review. Rome, Italy, FAO

Granades-Chinchilla, F. (2017). A focus on aflatoxin in feedstuffs: new developments in analysis and detection, feed composition affecting toxin contamination and interdisciplinary approaches to mitigate it. In AflatoxinControl, Analysis, Detection and Health Risks (pp. 252-280) Intech Open. https://doi.org/10.5772/intechopen.69498

Ghaemmaghami, S. S., Nowroozi, H. and Moghadam, M. T. (2018). Toxigenic fungal contamination for assessment of poultry feeds: mashed vs. pellet. Iranian Journal of Toxicology, 5: 5-10. https://doi.org/10.32598/ijt.12.5.534.1

Maciorowski, K.G., Herrera, P., Jones, F.T., Pillai, S.D., and Rickes, S.C. (2006). Effects on poultry and livestock of feed contamination with bacteria and fungi. Animal Feeds Science and Technology, 133(1): 109-136. https://doi.org/10.1016/j.anifeedsci.2006.08.006

Matthew, O., Chiamaka, R. and Chidinma, O. (2017). Microbial analysis of poultry feeds produced in Songhai farms, Rivers State, Nigeria. Journal of Microbiology and Experimentation 4(2): 1-3. doi:10.15406/jmen.2017.04.00110

Mehrolia, M.B., Kalkar, S.A. and Bhiwagade, S.D. (2015). Isolation and identification of fungi from poultry feed. International Journal of Researches in Biosciences, Agriculture and Technology, 1: 72-75. 
Mgbeahuruike, A. C., Nwoko, E. I. and Idolor, O. O. S. (2020). A survey of the aflatoxin level and molecular identification of fungal contaminants in poultry feed mills from different geopolitical zones of Nigeria. African Journal of Biotechnology, 19(8): 500-507. https://doi.org/10.5897/ajb2019.17043

National Research Council (NRC) (1994). Nutrient Requirements of Poultry. Washington DC. US: National Academic Press.

Nawabueze, A.A. and Nwabueze, E.O. (2011). Microbial flora of fish feeds sold in Asaba, Southern Nigeria. American Journal of Experimental Agriculture, 1(2):27-32.

Sukmawati, D., Saidah, N., Handayani, T. and Rahayu, S. (2018). The characteristics of fungi contaminating chicken feed in Regal, Bigot, West Java. Asian Journal of Agriculture and Biology, 6(4): 472-480.

Ubiebi, C.O. (2017). Isolation and identification of bacterial isolates from poultry and fish feeds sold in Abraka, Delta State, Nigeria. Journal of Industrial Technology, 2(1): 14-20.

Vakili, R., Torshizi, M.E., Yaghobzadeh, M.M. and Khadivi, H. (2015). Determination of chemical composition and physical feed quality of different processing parameters in broiler feed mill factories. Biological Forum, 7(1): 1098-1103. 